\title{
Towards Twenty-First Century Education : Success Factors, Challenges, and the Renewal of Finnish Education
}

\section{Lavonen, Jari}

Springer

2017

Lavonen , J \& Korhonen , T 2017 , Towards Twenty-First Century Education : Success Factors, Challenges, and the Renewal of Finnish Education . in S Choo, D Sawch , A Willanueva \& R Vinz (eds), Educating for the 21st Century : Perspectives, Policies and Practicies from Around the World . Springer, Singapore , pp. 243-264 . https://doi.org/10.1007/978-981-10-1673-8

http://hdl.handle.net/10138/310187

https://doi.org/10.1007/978-981-10-1673-8_13

unspecified

acceptedVersion

Downloaded from Helda, University of Helsinki institutional repository.

This is an electronic reprint of the original article.

This reprint may differ from the original in pagination and typographic detail.

Please cite the original version. 
Towards 21 st Century Education: $\square$ Success Factors, Challenges And Renewal Of Finnish Education

FULL REFERENCE Lavonen, J. \& Korhonen, T. (2017). Towards Twenty-First Century Education: Success Factors, Challenges, and the Renewal of Finnish Education. In Choo, S., Sawch, D., Willanueva, A., Vinz, R. (Eds.), Educating for the 21st Century: Perspectives, Policies and Practicies from Around the World. (pp. 243-264). Singapore: Springer.

Towards 21st Century Education:

Success Factors, Challenges, and the Renewal of Finnish Education

Prof. Jari Lavonen

Head of the Department of Teacher Education, University of Helsinki

Tiina Korhonen

Head of Innokas Network, Department of Teacher Education, University of Helsinki

Author Note

Contact address:

Department of Teacher Education, University of Helsinki

Siltavuorenpenger 5, 00014 University of Helsinki

Phone: +358504155317

Email: jari.lavonen@helsinki.fi 
Towards 21 st Century Education:

Success Factors, Challenges and Renewal of Finnish Education

\begin{abstract}
This chapter seeks to analyze the success factors, challenges, and renewal of Finnish education in the context of learning 21 st century competency. We analyze the good performance and low variation in performance of Finnish students and suggest Finnish teachers and teacher education as well as the Finnish approaches to curriculum, assessment and quality assurance as possible factors for the excellent results. In addition, we analyze possible reasons for the recent decline in assessment results. Challenges for Finnish education in the classroom, school, municipality, and national level as well as challenges in teacher education are considered. Finally, we introduce the new Finnish national curriculum and how it aims to develop the 21 st century competencies of students as a solution for overcoming the challenges. The creation of teacher collaboration networks is suggested as a way to support teachers' continuous professional development, particularly with respect to their teaching of 21 st century competency. We show how such networks could facilitate the creation and sharing of educational innovations related to teaching and learning through teachers' collaboration, inquiry, and problem-solving activities as well as through a close connection to classroom practice.
\end{abstract}

\title{
Finnish education context
}

Finland is situated in northern Europe, and its population, of which 90\% are Finnishspeaking Finns, is around 5.5 million, the majority being concentrated in its southern regions. The Finnish education system consists of daycare programs, a one-year "preschool" (for children aged six), a nine-year compulsory basic comprehensive school (starting at age seven and ending 
at age 15), post-compulsory secondary general academic and vocational education, higher education at universities and applied universities, and adult (lifelong, continuing) education. Finland has consistently ranked high in the Program for International Student Assessment (PISA) studies that compare national educational systems internationally (OECD, 2007; OECD, 2010), achieving not only high scores but also little variation in performance, an important outcome of national education policy. Several researchers and policymakers argue that this success is a consequence of Finland's education policy, structure, and practices (Burris, 2012; Sahlberg, 2011). The masters level teacher education programs have been named as particularly important reasons for the success (Laukkanen, 2008; Simola, 2005). However, when the PISA 2012 results were released, Finnish policymakers, researchers, and teachers encountered a new situation (Kupari, et al., 2013) due to a decline in PISA results (OECD, 2012). The percentage of weak performers in Finland had risen from $7 \%$ to $12 \%$, and the percentage of high performers in mathematics dropped from $23 \%$ to $15 \%$ compared to the previous PISA 2009 results. To find reasons for this decline, as well as new approaches to stop the decline, Minister of Education Krista Kiuru launched a project in spring 2014 to plan "Future primary and secondary education." As an outcome of this project, some speculative reasons for the decline, including reduced resourcing and non-engaging pedagogy, were suggested. In addition, recommendations for the development of primary, secondary, and teacher education were outlined (OuakrimSoivio, Rinkinen \& Karjalainen, 2015).

Knowledge-based society. The most important feature of Finnish education policy has been the commitment to a vision of a knowledge-based society. This vision can be found in national documents published as early as the 1970s, when the idea of introducing a common comprehensive school and university level teacher education was first presented (Jakku- 
Sihvonen \& Niemi, 2006; Simola 2005). A central aspect of the Finnish vision has been broad literacy and educational equality. As a part of this, the Finnish school curriculum emphasizes the learning of 21 st century competencies, such as critical and creative thinking and learning to learn (ways of thinking); the competence for inquiry, problem solving, communication, and collaboration (ways of working); the competence for using tools, including broad literacy and the use of technological tools; and the competence for acting in the world in different contexts (global and local) (Vahtivuori-Hänninen et al., 2014). The Finnish school curriculum also values all school subjects equally, with a dynamic balance between the arts, the humanities, and the sciences (Finnish National Board of Education (FNBE), 2004; Finnish National Board of Education (FNBE), 2013).

Educational equity. Key decisions on Finnish education policy were made in the 1970s, when, along with other Nordic countries, a change to a comprehensive obligatory school system was prescribed. According to the basic policy set at that time, all students should attend common comprehensive schools and learn together for as long as possible. Comprehensive school education is provided free of charge and includes schoolbooks, meals, transport, and health care. Although the policymakers' vision is that Finnish students should complete exactly the same nine-year comprehensive school education, some streaming of students according to ability does take place, for example, in mathematics and foreign languages at the school level. The equality policy encompasses special education practices, which aim to prevent students from dropping out and to support the learning of all students. Teachers do not consider their students as one entity; instead, teaching is adjusted to meet the personal needs of each student (personalized learning) (Jahnukainen, 2011). Altogether, 52\% of the schools participating in PISA 2012 in Finland reported that students were not grouped into different classes by ability in any subject. 
The corresponding percentages were $49 \%$ in Shanghai, 35\% in Canada, 32\% in the United States, 32\% in Singapore, and 21\% in Australia (OECD, 2013).

Culture of trust. An important general characteristic of Finnish education policy is the culture of trust: education policymakers and education authorities trust teachers, together with principals and parents, to decide on how to provide the best possible education for children and students at any given level (Simola, Rinne, Varjo, Pitkänen, \& Kauko, 2009). There has never been district or national level testing in the Finnish comprehensive school, nor have there been national or local school inspectors since the late 1980s. The teaching profession has always enjoyed great public respect and appreciation in Finland (Simola, 2005). Parents also trust the school, its teachers, and the quality of the work it undertakes. According to the PISA 2012 School Questionnaire data (OECD, 2012), only 4\% of Finnish schools reported being subject to constant pressure from parents. The corresponding percentages were $60 \%$ in Singapore, $36 \%$ in Australia, 35\% in the United States, 32\% in Canada, and 20\% in Shanghai (OECD, 2013).

\section{Reasons behind the success of Finnish education}

In general, Finnish students perform well. They have achieved high scores among OECD countries in assessments on reading, mathematics, and scientific literacy. Moreover, the low variation of performance in the results indicates that overall, the performance of all teachers and schools is very similar. The aim of this section is to analyze the reasons for the good performance and low variation in performance. In practice, Finnish teachers and teacher education as well as the Finnish approaches to curriculum, assessment and quality assurance are analyzed.

Finnish teachers are professional teachers. A professional teacher, internationally, is supposed to have a profound and versatile knowledge base. This professionalism is based especially on the level and depth of the teacher's subject matter knowledge, as well as on his or 
her knowledge of pedagogy (Carlsen, 1999; Gess-Newsome, 1999). Professional teachers collaborate with other teachers in planning, implementing, and assessing their own teaching and their students' learning and, moreover, constantly work to improve their teaching based on these assessments. They formatively monitor the progress of their students, particularly those with special needs, and try to support all students' learning (DuFour, 2006). These characteristics of a professional teacher are the core aims in Finnish Master's level teacher education programs (Kansanen et al., 2000; Lavonen et al., 2007; Niemi, Toom \& Kallioniemi, 2012).

Altogether, $60 \%$ of Finnish teachers and principals like their job and feel that their work in education is valued highly in Finnish society (Taajamo, Puhakka \& Välijärvi, 2014). In our neighboring country, Sweden, only $5 \%$ of teachers believe that their work is appreciated. Finnish teachers are pleased with what they do in school (95\%) and enjoy their work (91\%). They would recommend their school as a good place to work (88\%), and if they had to choose again, they would still choose the teaching profession (85\%) (OECD, 2013).

Teacher education in Finland. Professionalism is not only a characteristic of the Finnish teacher but also of the whole Finnish education context (Krzywacki, Lavonen, \& Juuti, 2015). This aim is pursued by providing five-year master's-level programs at universities for primary and secondary school teachers, with a core objective to train professional teachers (Kansanen et al., 2000; Jakku-Sihvonen \& Niemi, 2006; Lavonen et al., 2007; Sahlberg, 2011; Niemi, Toom \& Kallioniemi, 2012). The decision to do so was made more than 40 years ago, in 1974, when separate teacher education colleges and teacher training schools were merged to form departments within universities. From the very beginning, the objective of teacher education has been to make sure teachers not only have a high level of teaching expertise but are also capable 
of professional and autonomous planning, including the planning of a local-level curriculum, as well as implementing and assessing their own work.

The aim of teacher education is to educate "teacher leaders" (Krzywacki, Lavonen, \& Juuti, 2015) in the context of "teacher leadership" thinking (Katzenmeyer \& Moller, 2001, p. 17). Based on the national teacher education documents, Lavonen, Krzywacki-Vainio, Aksela, Krokfors, Oikkonen, and Saarikko (2007) have outlined three areas of aims for teacher education that are closely aligned to teacher leadership thinking:

1. High-quality knowledge base, including high-level subjects, pedagogical content knowledge, contextual knowledge, an ethical code, and social skills, such as for communication and ICT use.

2. Competence to operate in networks and partnerships, including knowledge about school as an institute and its connections to the society, and collaboration skills with teachers, parents, and stakeholders around the school.

3. Competence for life-long-learning, including the skills needed in developing one's own teaching, in the teaching profession, and in the local curriculum, as well as academic skills in terms of being able to conduct high-quality research.

National and local curriculum. The curriculum cycle in Finland is approximately 10 years. The latest revision of the National Core Curriculum for Basic Education (NCCBE), replacing the previous one from 2004, was published in 2014, with its introduction to service scheduled for 2016. According to Vitikka, Krokfors, and Hurmerinta (2012), the current national curriculum system in Finland has three key driving factors: 1) a description of broad goals following national core values, such as human rights, equality, democracy, and natural diversity, and a discussion of 21 st century competencies; 2) the autonomy of municipal authorities in 
providing and organizing education, so that the local curriculum is the guiding document at the local level; and 3) different approaches to schoolwork (Vitikka, Krokfors, \& Hurmerinta, 2012; Finnish National Board of Education (FNBE), 2013). Consequently, the Finnish approach to curriculum differs from the outcome-based approach that encompasses a detailed description of intended learning outcomes (Spady, 2003).

Education in Finland is arranged by local authorities (municipalities), and schools operate under their jurisdiction. The core curricula are prescriptive to the providers of education, who are obliged to draw up the local curricula based on them (Halinen, Holappa, \& Jääskeläinen, 2014). However, local education providers have extensive autonomy in Finland; the municipal curriculum is decided upon by municipal education authorities. They are responsible for planning the local curriculum, organizing assessments, and using the data obtained to evaluate how well the curricular goals have been achieved. Moreover, the municipalities have a great deal of autonomy in preparing the school budget, in setting group sizes, and in other operations at the school level.

The local-level curriculum is a dynamic and flexible document, designed at the grassroots level as a joint effort between principals, teachers, and parents, as well as local community organizations, such as athletic and cultural groups. The local curriculum is seen more as a process than as a product, and it has a central role in school improvement (Lavonen, 2007).

Consequently, a productive, flexible interaction exists between partners at the national, municipal, and school levels. This long-term process has a central role in school improvement and development. According to the PISA 2012 School Questionnaire (OECD, 2012), al together $62 \%$ of the participating schools in Finland reported that a principal and the teachers were responsible for curriculum policy. The corresponding percentages were $68 \%$ in Australia, $48 \%$ in 
Singapore, $47 \%$ in Canada, $44 \%$ in the United States, and 28\% in Shanghai. Preparing the local curriculum has a central role in school improvement and development.

Quality assurance and assessment. The Finnish approach to quality assurance (QA) is not based on school inspections, systematic national testing, or pre-evaluation of learning materials. Neither teachers nor the quality of their teaching are assessed on the basis of their students' learning outcomes or other indicators. According to the PISA2012 School Questionnaire data, only about $10 \%$ of Finnish teachers feel that the quality of their work is evaluated by the principal more than once in a term. The corresponding percentages were $61 \%$ in the United States, $42 \%$ in Canada, 33\% in Australia, 30\% in Shanghai, and 16\% in Singapore. However, small-scale, sample-based monitoring designed by the National Board of Education is carried out infrequently with a representative sample of teachers (Kärnä \& Rautopuro, 2013). The information gathered from these is mainly used for curriculum development and as a basis for educational policy.

In addition to this type of national monitoring, QA is organized through self-assessment at the school and municipality levels. For example, the principals organize professional development discussions with teachers to support their self-assessment. Schools collect feedback from students and parents and analyze this feedback in teacher meetings to improve teaching and school operations. Moreover, self-assessments are discussed at municipality level, which means that there is interaction between the levels (Simola et al., 2009). QA is seen as a part of policy of enhancement and as a tool for improvement, not as a reason to impose sanctions or penalties (Niemi \& Lavonen, 2012).

Internationally, the roles of teachers in assessment and assessment policy may be in conflict. Teachers aim to organize their classroom practice in such a way as to fulfill the 
requirements of the curriculum. They may find that top-down educational policy and bureaucratic measures threaten their feeling of expertise and confidence as teachers (InbarLourie \& Donitsa-Schmidt, 2009; Black \& Wiliam, 2003). Moreover, teachers may not feel that feedback from an external assessment is pedagogically relevant to improving their methods and activities but instead experience it as external control and consequently as a threat to their professionalism (Maier, 2009).

Assessment in Finland is internal, emphasizing teacher-conducted procedures, such as formative forms of assessment and self-assessment (Black \& Wiliam, 2003; Inbar-Lourie \& Donitsa-Schmidt, 2009). There is no national or district-level testing. A non-competitive and non-judgmental atmosphere in assessment makes the professional life of Finnish teachers enjoyable. Because of this non-competitive atmosphere, teachers are eager to collaborate. The focus on internal assessment is also seen in the PISA 2012 School Questionnaire (OECD, 2013b): 70\% of Finnish teachers feel that student assessment is their responsibility. The corresponding percentages were $70 \%$ in Australia, $58 \%$ in Canada, $49 \%$ in Singapore; $40 \%$ in the United States, and 33\% in Shanghai. This internal assessment and Finnish teachers' autonomous role in assessment are supported by Finnish education policy and context. Assessment in Finland serves various functions, including the improvement of classroom practice and student learning processes, as well as the monitoring of the quality of teaching (Krzywacki, Koistinen, \& Lavonen, 2012). However, as in other countries, the variety of uses, users, and methods makes assessment complex in Finland. 


\section{Challenges of Finnish education}

Although the Finnish PISA results are high, they are declining. Therefore, the second aim of the chapter is to analyze the challenges for Finnish education and possible reasons for the declining PISA results. Despite the success of Finnish students and the whole education context, several challenges arising from the 21 st century megatrends of globalization, digitalization, and mobile learning have been identified. Next, the challenges are analyzed through the 21 st century competencies context on the classroom, school, municipality, and national levels.

21st century competencies. The "21st Century Skills" movement refers to the redefinition of educational goals and to ways of organizing learning to meet the demands of the 21st century (Trilling \& Fadel, 2009; Binkley et al., 2012). Several research studies, for example OECD PISA (OECD, 2006) and DeSeCo (OECD, 2005), have tried to specifically describe what kinds of competences people should have to achieve personal, social, and economic success.

In the DeSeCo project, OECD (2005) analyzes 21 st century competence in the context of the future of work life. They emphasize the need for an ability to meet complex demands by drawing on and mobilizing psychosocial resources (including knowledge, skills, and attitudes) in a particular context. In the DeSeCo project, OECD collaborated with scholars and experts to identify a small set of key competencies, rooted in a theoretical understanding of how such competencies are defined. According to the DeSeCo project, each key competency must contribute to valued outcomes for societies and individuals, help individuals meet important demands in a wide variety of contexts, and be important not just for specialists but for all individuals. Individuals need to be able to use a wide range of tools, including socio-cultural (language) and technological (ICT) tools, to interact effectively with the environment, to engage and interact in a heterogeneous group, to take responsibility for managing their own lives, and to 
act autonomously. Although DeSeCo focuses on the needs of working life, the ideas could be interpreted in the context of school. In this interpretation, it is important to remember that the students are novices, still learning these competences.

The PISA Science Framework (OECD, 2006) defines three science competencies, which describe the use of science subject knowledge and knowledge about science generally, as well as the willingness to use this knowledge (attitude) in three situations: in identifying scientific issues, in explaining scientific phenomena, and in drawing evidence-based conclusions. Therefore, the PISA framework emphasizes a scientific, or critical, way of thinking, giving value to the use of evidence in argumentation or research-based knowledge in explaining. In a similar way, PISA Reading Literacy refers to the capacity to understand, use, and reflect on written texts to achieve one's goals, develop one's knowledge and potential, and participate in society. PISA Mathematical Literacy refers to the capacity to identify and understand the role that mathematics plays in the world, make well-founded judgments, and use and engage with mathematics in ways that meet the needs of one's life as a constructive, concerned, and reflective citizen.

Consequently, PISA focuses on critical thinking, the use of evidence in thinking, and the use of knowledge in thinking.

An important challenge for all individuals is to learn creative thinking and to acquire the capability to innovate (Rotherham \& Willingham, 2009). Piirto (2011) provides a careful analysis on how to embed creativity into the classroom and suggests three main views:

1. Think creatively: use a wide range of idea creation techniques (such as brainstorming); create new and worthwhile ideas (both incremental and radical concepts); elaborate, refine, analyze, and evaluate ideas to improve and maximize creative efforts. 
2. Work creatively with others: develop, implement and communicate new ideas to others effectively; be open and responsive to new and diverse perspectives; incorporate group input and feedback into the work; demonstrate originality and inventiveness in work, and understand the real-world limits of adopting new ideas; view failure as an opportunity to learn; understand that creativity and innovation are a long-term, cyclical process of small successes and frequent mistakes.

3. Implement innovations: act on creative ideas to make a tangible and useful contribution to the field in which the innovation will occur.

Table 1 summarizes the competencies that individuals need to lead a successful and responsible life and that society needs to face present and future challenges. However, choosing teaching methods that support students in learning these competencies is not straightforward because students come with diverse backgrounds and achievement levels that impact their ability to learn. Therefore, it is important to utilize a variety of teaching methods that help learners build their own understanding through real-world applications and interactions, in small groups, with their peers. To be productive contributors to society in our 21st century, you need to be able to quickly learn the core content of a field of knowledge while also mastering a broad portfolio of essentials in learning, innovation, technology, and careers skills needed for work and life (Trilling \& Fadel, 2009, p. 16; see also, Binkley et al., 2012). Students should be educated for jobs that have not yet been created, for new products that have not yet been invented, and for new skills that build towards creativity and innovation. 
Table 1.21 st century competencies as ways of thinking and working

\begin{tabular}{|c|c|}
\hline $\begin{array}{l}\text { Competences needed in } \\
\text { the } 21 \text { st century }\end{array}$ & Examples of competences \\
\hline \multirow[t]{3}{*}{ Ways of thinking } & Creative and critical thinking \\
\hline & Use of knowledge and information interactively \\
\hline & Learning to learn, use of metacognition \\
\hline \multirow[t]{6}{*}{ Ways of working } & $\begin{array}{l}\text { Communication, collaboration, and networking (teamwork in a } \\
\text { heterogeneous group) }\end{array}$ \\
\hline & Competence to act autonomously \\
\hline & $\begin{array}{l}\text { Identifying issues (questioning), arriving at conclusions based on } \\
\text { information, explaining phenomena, and organizing information }\end{array}$ \\
\hline & $\begin{array}{l}\text { Competence to use both creative and critical thinking in problem- } \\
\text { solving and decision making }\end{array}$ \\
\hline & Use of ICT tools interactively \\
\hline & Managing and resolving conflicts \\
\hline \multirow[t]{4}{*}{ Tools for working } & $\begin{array}{l}\text { Literacy: knowledge (network of concepts), nature of knowledge, } \\
\text { and attitude (willingness to engage) }\end{array}$ \\
\hline & ICT literacy \\
\hline & Skills needed in inquiry and problem solving \\
\hline & Moral and ethical code \\
\hline \multirow[t]{4}{*}{ Context for working } & Personal, citizenship \\
\hline & Social, local \\
\hline & Working life, career \\
\hline & Global \\
\hline \multirow{2}{*}{$\begin{array}{l}\text { Attitude needed for } \\
\text { working }\end{array}$} & Willingness to use knowledge (motivation) \\
\hline & Self-efficacy \\
\hline
\end{tabular}

Challenges in the classroom. The key challenge on the classroom level is to find ways to guide students to learn 21 st century competencies. Teachers and school leadership must consider the impact of teaching 21 st century competencies to the practical operational arrangements in the classroom and in the school. This may prove challenging because current 
teacher-led learning methods do not support the learning of 21 st century competences. In addition, the school may need to invest in the redesign of its physical learning spaces and assign parts of its already scarce resources to the purchase of new learning resources.

On the classroom level, the successful implementation of the teaching of 21 st century competencies calls for 1) the recognition of students' individual backgrounds and ways of learning, 2) the introduction of new versatile and engaging teaching methods, 3) the versatile utilization of different learning environments, and 4) the empowerment of students to influence their learning, the ways of teaching and learning, and the learning environments and operational practices in the classroom and in the school.

By recognizing the preferred learning style and rhythm, as well as the personal interests and hobbies of each student, the teacher can design personalized learning that finds the right balance between individual and group creative thinking and makes clever use of the students' own interests to get them engaged in creating and implementing innovations.

New, versatile learning and teaching methods include authentic learning-project-based learning that is grounded in real-life challenges. These methods include widely scoped project work that encourages students to make use of the knowledge and skills they have acquired in various school subjects while they are exposed to various teaching practices that encourage them to try new things and to nurture and develop their ideas (Lavonen, Korhonen, Kukkonen \& Sormunen, 2014)

The learning environments in a school comprise both physical and virtual environments. To enable the learning of creativity and innovation, the school should allow and encourage learning wherever it takes place naturally: in a classroom, in the hallways, outdoors, or in other locations, such as in a community library. The key challenge for the school is to cross the 
boundaries of the traditional classroom and start using out-of-classroom spaces for teaching and learning. Moreover, digital environments such as Google Drive expand the spaces that students engage with in their learning. These new spaces create learning environments supportive for the learning of 21 st century competences. However, the environments in and of themselves do not create 21 st century learning — novel pedagogical innovations are needed. Lavonen, Korhonen, Kukkonen \& Sormunen (2014) describe several pedagogical innovations designed for new environments and supportive for learning of 21 st century competences. Among these innovations is the versatile use of smartphones in science learning to personalize students' learning. Another example is School-Community Collaboration (SCC) with the local library, kindergarten, and senior home. In this pedagogical approach, students engage in SCC that has been designed collaboratively between teachers, students, and out-of-school collaborators. The SSC supports students in planning their own learning and project tasks collaboratively, lets them choose their preferred ICT tools, allows them to interact with each other in small groups where they can share responsibilities, and lets them self-evaluate their project work, learning progress, and accomplishments.

Challenges in the school. In schools and school districts, operational practices and leadership structures need to be reengineered to support the learning of the 21 st century competencies. Teachers may feel that their individual competency is insufficient to address the new teaching challenges in their classroom. They would need additional competency to support students in learning critical and creative thinking skills as well as to guide students' collaborative inquiry and problem-solving activities. In the Finnish primary school context, it may be especially difficult for a professional teacher to recognize that in working alone, he or she cannot understand and teach all the aspects related to the teaching and learning of 21 st century 
competencies. Schools should recognize this and steer away from the traditional Finnish concept of the "lone wolf" teacher towards the teacher as learning facilitator who works flexibly with the school's teaching and non-teaching staff to complement his or her own knowledge and skills in the context of the teacher leadership movement (Lieberman, 1992; Harris, 2003; Katzenmeyer \& Moller, 2001, p. 17).

To enable the versatile ways of learning called for in the classroom, the school needs to take steps to establish the school as a safe, supportive environment within both its physical and virtual extents. The school must safeguard students' physical and mental health. This includes insisting on an immediate response to bullying, while encouraging as much flexibility in learning and student interaction as possible. The school needs to organize interdisciplinary work that integrates the various professionals in the school: teachers, teaching assistants, school managers, school nurses, counselors and psychologists; into a team that works together with parents to address any issues and that empowers students to have their say in any proposed action.

The learning of 21 st century competencies calls for versatile physical and virtual learning environments that extend beyond the school's perimeter. Students learn everywhere and should be supported wherever they learn. This requires the school to establish and maintain effective local collaboration networks, not only with other community institutions such as kindergartens and libraries but also with parents and other members of the local community. This needs leadership and readiness from teachers' side for this type of networking. In addition, to learn about and share best practice in the learning of 21 st century competencies, the school needs to establish and maintain professional networks with other schools and with national and global initiatives that allow the exchange of experiences and ideas. 
When using the Internet, students are exposed to a global virtual learning environment. To make this environment safe and understandable for them, it is important that the school establishes network contacts that allow them to engage readily with students from other parts of the world. This in turn enables them to understand themselves as a part of global humanity, to, take their first steps along the way to becoming "world citizens," and to appreciate different cultures, traditions, and ways of working.

The challenges posed by the learning of 21 st century competencies are not static and thus cannot be solved once and for all. Instead, the school needs to become a learning organization, flexibly evolving its operational practices to align with evolving challenges. For this to happen, continuous quality assurance monitoring of school operations should be established to support the further, collaborative development of the school and its networks.

Challenges at the municipality level. The previous analysis of the challenges at the school level could be summarized as follows: to support students in learning 21 st century competences, the school should emphasize versatile leadership, teachers' professionalism, meaningful learning in versatile physical and virtual learning environments, and, moreover, the versatile use of networks and partnerships of the school. These four characteristics activate teachers, students, school principals, parents, and other collaborators from the nearby community to continuously develop the school operations supportive for learning the 21 st century competences. (Korhonen, Lavonen, Kukkonen, Sormunen \& Juuti 2014)

Consequently, at the Finnish municipality level, a key challenge is helping schools develop the four key characteristics that support the teaching and learning of 21 st century competencies. Local education policymakers face the challenge of establishing a strategy-based school network that supports schools in collaboratively developing the four areas. As Finnish 
municipalities face severe challenges in their long-term financing, calling for increased productivity in public services, the community needs to simultaneously find efficiencies in the design of the school network.

Although the Finnish tradition discourages emphasis on school assessment and rankings, an approach being considered is to collect and use school-level assessment data to feed into decision-making on the allocation of resources. Accurate assessment data would allow decisionmakers to balance different equity areas and to determine the optimal learning conditions, notably class sizes, for each area.

National-level challenges. At the national level, the learning and teaching of 21 st century competencies challenges education policymakers to develop appropriate nationwide guidance for the challenges mentioned above. In addition, national-level policymakers need to review the current teacher education curriculum and professional development programs offered to inservice teachers and school management to align them with the teaching and school management challenges introduced by the teaching of 21 st century skills. In addition, current national policies related to QA and assessment, the long-term funding and productivity of education as a public service, and its equal availability to all inhabitants need to be reviewed in the light of the new challenges.

Challenges for teacher education. A recent international teaching and learning study, TALIS 2013 (Teaching and Learning International Survey) (OECD, 2014), demonstrated several weaknesses in school operations (Taajamo, Puhakka, \& Välijärvi, 2014). According to the TALIS study, most Finnish teachers find that they are able to influence factors that promote learning. However, according to TALIS, teachers' participation in continuous professional development seems to be fading. In particular, the demand for continuing education that meets long-term 
challenges and develops professional competence is decreasing. Moreover, TALIS emphasizes that induction and orientation for new teachers has a low take-up in Finland. Teachers feel that initial teacher education does not prepare them sufficiently for 21 st century challenges, such as collaboration between home and school, multi-professional co-operation, controlling disruptive behavior in the classroom, or catering to the needs of challenging students.

To develop the additional knowledge and skills teachers need for teaching 21 st century competencies, teachers should be encouraged to organize and participate in professional development programs and other in-service training as a natural part of their career development. Faced with new challenges in their classroom, teachers can no longer expect to be able to run their classroom in a "lone wolf" fashion with no significant retraining over the course of their entire professional career. As this is a significant change to the self-image of a professional teacher, national policy and local providers of education (municipalities) should consider measures that support teachers, especially those who have advanced far into their career, in adopting the new image as a coach or facilitator to other teachers. Moreover, university teachers delivering teacher education and professional development programs for in-service teachers confront similar challenges as classroom teachers: the university teacher does not have personal experience in teaching 21 st century competencies, yet is expected to guide student teachers and in-service teachers in doing the same.

However, it is difficult to organize an effective professional development program or an in-service program in practice. Borg (2011) argues that in-service training is too often conducted according to the "transmission model," in which the aims of the training do not necessarily meet the needs of the teachers; it consists of short lectures, with the aim to transmit new knowledge (input-based), and the training is disconnected from practice. Borg (2011) argues that in-service 
training should follow a more "constructivist model"; it should be teacher-led, continuous, situated in or connected to the classroom context, collaborative, and inquiry oriented, including reflective practice (Lavonen, Juuti, Aksela, \& Meisalo, 2006; Juuti, Lavonen, Aksela, \& Meisalo, 2009). Constructive models for in-service training would appear ideal for enabling teachers to teach and students to learn 21 st century competencies, with which they align well. Such models could help teachers to internalize the meaning of these competences. During their preservice training, student teachers should develop a readiness to participate in constructivist in-service training and ultimately in lifelong learning. They should, for example, be introduced to the role of leadership and goal orientation and to the importance of interaction. Moreover, student teachers should understand the role of assessment in education: targets (student, teacher, and school operations), self-assessment (formative and summative) and assessment methods, and the use of assessment data for various purposes (support for learning, additional support, or differentiation for individual students).

In-service training or professional development should enable teachers to support their students' engagement in learning and enhance their existing skill sets with new, versatile pedagogy that supports the learning of 21 st century competences and personalized learning. Teachers should also develop skills in new topics, such as global citizenship, democracy, and equality education, and in the use of new tools, notably educational technology. The challenges posed by the teaching of 21 st century competence also call for an expanded role for teachers outside the classroom. To prepare for this, teachers should develop an understanding of the role of networks and partnerships at the school and municipality levels as well as an understanding of the continuous and collaborative improvement of school operations. As a part of a school's quality assurance procedures, the principal and teachers should continuously monitor how the 
curriculum, teaching, and learning methods at the school engage students to learn 21 st century competences. Moreover, new methods and tools for assessing the learning outcomes related to 21 st century competences are needed. Traditional "testing" might not be the best choice for assessing 21 st century competences.

Quality assurance challenges. Although the Finnish approach to QA does not place great weight on testing and assessment, changes to educational policy intended to support the teaching of 21st century competences should include new ways to assure the quality of policy implementation. 21 st century competence includes competencies such as local and global collaboration skills, which cannot be measured using current forms of assessment. As new forms of measurement for such competencies are needed all over the world, their development would benefit from global research collaboration.

To enable the implementation of changes that meet the challenges, national policy should allocate resources to strategic areas, financing research and development as well as lifelong professional development projects. With limited resources allocated to education in the national budget, the productivity of public services is an important consideration in any new policy development. Traditionally, new national-level education development initiatives start their work from scratch and end up reinventing tools and redeveloping competencies that would already be available for reuse from previous programs. New initiatives should therefore seek to use existing assets and competencies. In addition, resourcing should focus on reinforcing success by funding long-term development that continuously creates new results built on earlier results, and should include provisions for the nationwide dissemination of best practices. For example, initiatives to develop national-level learning environments, including cloud services and virtual learning centers for teachers and students, should make use of existing competency available from 
previous initiatives. Furthermore, for educational equity, it is important to make sure that the cost of teaching 21 st century competencies does not prohibit it from becoming available to all students, thus setting a limit for the cost of any solutions prescribed by national policy.

\section{Renewal of Finnish education}

The new national-level curriculum. To address the challenges analyzed above and to help students learn 21st century competencies, a new national-level curriculum has been developed. During the five-year design process of the curriculum, the need for 21 st century competencies or skills has influenced the design of the curriculum in Finland and in many other countries (Vahtivuori-Hänninen et al., 2014; Finnish National Board of Education (FNBE), 2013). The new Finnish curriculum, NCCBE (Finnish National Board of Education (FNBE), 2013), was accepted in December 2014 and will guide all schools towards preparing a local curriculum that will be implemented from the beginning of 2016.

The new NCCBE outlines the need for broadly scoped competency that aligns with 21 st century competences, including the competencies described in Table 1, such as critical and creative thinking, and an ability to use a wide range of tools, such as socio-cultural (language) and technological (ICT) tools. Table 2 compares the interpretation of the 21 st century competences in the new Finnish curriculum and the interpretation of the 21 st century competences outlined earlier (Table 1). The new curriculum emphasizes that students' wellbeing, defined as the balanced development of personality and the ability to manage daily life, is also an important goal of learning. According to the curriculum, students' physical and emotional well-being should be supported through school and classroom operations. At the school site, there should be different actions and support available, such as an anti-bullying program, a 
school nursery, a social worker, and psychology services. The use of ICT may provide many tools for active and meaningful learning.

Table 2. Comparison of 21st century competences (Table 1) and Finnish border-crossing wideranging areas of competences.

\begin{tabular}{ll}
\hline 21st century competences (Table 1) & $\begin{array}{l}\text { Finnish border-crossing wide-ranging } \\
\text { areas of competences }\end{array}$ \\
\hline
\end{tabular}

Ways of thinking

- Critical and creative thinking - Thinking and learning to learn

- Learning to learn

\section{Ways of working}

- Inquiring and problem solving

- Communication and

- Inquiry orientation,

- Interaction and communication

collaboration

\section{Tools for working}

- Broad literacy

- Technological skills
- Multi-literacy

- ICT competence

\section{Acting in the world/contexts}

- Global and local citizenship

- Cultural awareness and social responsibility
- Taking care of your-self, everyday

life skills, safety

- Working life skills and entrepreneurship

- Participation and influence, responsibility for sustainable future 
Success in implementing the thinking of the 21 st century competency movement through the new NCCBE, as manifested in the local curriculum, depends on teachers' competencies and on the support available for them. Teachers may not yet possess the knowledge and skills that would enable them to successfully teach 21 st century competences. In addition, teachers may feel insecure with or even fear the teaching of 21 st century competences, as it involves project-based and inquiry-oriented learning methods and, moreover, integration of technology, which are not part of their existing competences. This gap between the needed and current teaching practices have been reported in national PISA reports (Kupari et al., 2013) and in national monitoring reports (Kärnä \& Rautopuro, 2013).

The previous NCCBE (Finnish National Board of Education (FNBE), 2004) already incorporated competencies related to 21 st century skills, such as the use of technology and the understanding of technology as part of society. When the previous NCCBE came into effect, incorporating these parts into the local curriculum proved challenging for teachers and headmasters, and they sought additional guidance on both the peer level and from national authorities. The main reason for these challenges was the need to combine the aims related to 21 st century competences with subject-specific aims. The new curriculum encourages an even deeper combining of these two groups of aims. Thus, we can expect that the new NCCBE, with its more direct call for the incorporation of 21 st century competencies into the curriculum as part of broad-based competency, is likely to raise the same and additional challenges. The core challenge is the need for teachers and headmasters to start the task of teaching 21 st competencies to students while simultaneously trying themselves to learn the 21 st century competencies that enable them to do so. 
New forms of professional development. The image and forms of professional development programs for in-service teachers should be reshaped to meet the new challenges. A professional development program does not necessarily need to consist of a single high-profile seminar, but can instead take flexible forms that initiate and enhance collaboration among both teachers and learners. Professional development should be a lifelong activity, supported by a personal development plan for teachers and school principals.

To realize new types of professional development practices, preservice and in-service teacher education should prepare teachers for collaboration and continuous team-based professional development. Lieberman (1992) and Harris (2003) have outlined the knowledge base of this type of teacher leader. Such teachers are goal oriented and have a clear vision of school development and are able to work collaboratively and in interaction with other teachers towards their goals. They are capable of absorbing and assimilating research-based knowledge and have a deep understanding of teaching and learning, which allows them to act as curriculum specialists. A teacher leader is a facilitator and a coach for other teachers.

Several changes on the national level are needed to bring more teacher leaders to schools. Although several national and municipality level meetings and other in-service training will be available, addressing this core challenge requires the recognition of a number of operational challenges on the classroom, school, community, and national levels. A national project for harmonizing teacher education programs in various universities and for balancing academic and professional aims is needed. In practice, strategy-based planning of teacher education and continuous QA (use of working life feedback, students' evaluations, and the outcomes of research) are needed, as well as research projects that can lead to productive teacher education and offer appropriate content to teacher education programs. 
In chapter x, Korhonen and Lavonen describe the Innokas Network (Korhonen \& Lavonen, 2016), which has been established in Finland for the nationwide sharing of best practices related to the learning of 21 st century competences. Continuous design and adoption of educational innovations in collaborative teacher teams inside a school and in teams of teachers coming from different schools is suggested as an alternative form for teachers' professional development. The key guiding idea is that teachers and students themselves are innovators (Korhonen \& Lavonen, 2016). In general, such networks support teachers’ professional development because they encourage the generation, sharing, and adoption of novel educational ideas among network participants (Rogers, 2003). Further, such networks create environments or cultures for learning, in which participants learn and use new knowledge and skills in different contexts (Epstein, 2009).

\section{Discussion}

Professional teachers are at the center of addressing the challenges arising from new national initiatives, including those associated with the introduction of 21 st century competencies into the Finnish national curriculum. This raises the question of what changes should accordingly be made to both in-service and in initial teacher education. Teacher education should consider the current baseline knowledge on 21 st century skills, the currently available best practices of teaching them, and proficiency in continuous improvement methods that allow teachers to both contribute to the national pool of knowledge and implement national education policy initiatives in their school. Preservice teacher education should especially develop readiness for collaboration and networking and for continuous lifelong learning as outlined above and in chapter x. Although, Finnish preservice teacher education does emphasize teacher leadership, teachers should receive in-service support or training on leadership so that they can act 
individually and as part of a team in the continuous design and implementation of educational innovation. These measures may provide a partial solution to the challenges identified at the school, municipality, and national level.

The nationwide sharing of best practices requires the establishment and maintenance of teacher and school collaboration networks, such as the Innokas Network (Korhonen \& Lavonen, 2016) that is introduced in chapter X. Such networks could work by facilitating face-to-face meetings and the use of new social networking tools. Teachers' collaboration in the networks starts from the needs of the teachers and includes both the creation of educational innovations and their application in the classroom. Therefore, the networks serve the learning and development needs of the students in the classrooms. Further, such networking supports integrating inquiries, problem solving, and reflective practice as a part of professional development. There is a close connection to classroom practice (Borg, 2015), which is regarded as central for teachers' professional and ongoing development (Lavonen, Juuti, Aksela, \& Meisalo, 2006; Juuti, Lavonen, Aksela, \& Meisalo, 2009). As far as possible, such collaboration networks should be aligned with existing structures at the school, municipality, and national levels, without sacrificing the peer-to-peer nature of the teachers' interaction model.

Teachers tend to teach as they are educated (Borg, 2015). Teachers' in-service training that aims to support the learning of 21 st century competences should engage teachers in professional development practices that are themselves based on 21st century competencies. Teachers should proactively set aims for activities and generate, implement, and test (evaluate) educational innovations, and they should engage in decision making. Networking as such is one of the 21 st century competencies; in addition, it facilitates communication and collaboration (Rogers, 2003). Large amounts of information are mediated through ICT tools in networks, and 
consequently, networks facilitate learning about the use of ICT tools. Problem solving and collaboration in the context of networking emphasize both creative and critical thinking and the interactive use of knowledge and information. Finally, working in networks includes various working contexts: personal, social, and even global. The teachers active in the Innokas Network (Korhonen \& Lavonen, 2016) have already created several pedagogical innovations, such as School-Community Collaboration (SCC) with the library, kindergarten, and senior home, as well as the personalization of learning through the use of smart phones as described above (Lavonen, Korhonen, Kukkonen \& Sormunen, 2014). These innovations have already been deployed through the Innokas Network and will be distributed wider in the future. 


\section{References}

Binkley, M., Erstad, O., Herman, J., Raizen, Senta, Ripley, M., . . Rumble, M. (2012). Defining twenty-first century skills. In P. Griffin, \& E. Care (Eds.), Assessment and teaching of 21st century skills (pp. 17-66). Netherlands: Springer.

Black, P., \& Wiliam, D. (2003). In praise of educational research: Formative assessment. British Educational Research Journal, 623-637.

Borg, S. (2011). The impact of in-service teacher education on language teachers' beliefs. System, 39(3), 370-380.

Borg, S. (2015). Teacher research for professional development. In G. Pickering, \& P. Gunashekar (Ed.), Innovation in English language teacher education (p. 23). British Council. Retrieved 10 11, 2015, from http://www.britishcouncil.in/sites/default/files/tec14_papers_final_online.pdf

Burris, J. E. (2012). It's the teachers. Science, 335(6065), 146.

Carlsen, W. (1999). Domains of teacher knowledge. In J. Gess-Newsome, \& N. G. Lederman (Eds.), Examining pedagogical content knowledge (pp. 133-144). Netherlands: Kluwer Academic Publishers.

DuFour, R. (2006). What is a "professional learning community"? Educational leadership, 61(8), $6-11$.

Epstein, J. M. (2009). School, family, and community partnerships: Your handbook for action. Thousand Oaks, CA: Corwin Press.

Finnish National Board of Education (FNBE). (2004). National core curriculum for basic education. Helsinki: National core curriculum for basic education. Retrieved 10 11, 2015, from http://www.oph.fi/download/139848_pops_web.pdf 
Finnish National Board of Education (FNBE). (2013). OPS 2016 - Renewal of the core curriculum for pre-primary and basic education. Helsinki: Finnish National Board of Education. Retrieved 10 11, 2015, from http://www.oph.fi/download/151294_ops2016_curriculum_reform_in_finland.pdf

Gess-Newsome, J. (1999). Pedagogical content knowledge: An introduction and orientation. In J. Gess-Newsome, \& N. G. Lederman (Eds.), Examining pedagogical content knowledge (pp. 3-17). Netherlands: Kluwer Academic Publishers.

Halinen, I., Holappa, A.-S., \& Jääskeläinen, L. (2014). Opetussuunnitelmatyö ja yleissivistävän koulutuksen uudistaminen. Kasvatus: Suomen kasvatustieteellinen aikakauskirja, 44(2).

Harris, A. (2003). Teacher leadership as distributed leadership: Heresy, fantasy or possibility? School leadership \& management, 23(3), 313-324.

Inbar-Lourie, O., \& Donitsa-Schmidt, S. (2009). Exploring classroom assessment practices: The case of teachers of English as a foreign language. Assessment in Education: Principles, Policy \& Practice, 16(2), 185-204.

Jahnukainen, M. (2011). Different strategies, different outcomes? The history and trends of the inclusive and special education in Alberta (Canada) and in Finland. Scandinavian Journal of Educational Research, 55(5), 489-502.

Jakku-Sihvonen, R., \& Niemi, H. (Eds.). (2006). Research-based teacher education in Finland: Reflections by Finnish teacher educators. Turku: Finnish Educational Research Association.

Juuti, K., Lavonen, J., Aksela, M., \& Meisalo, V. (2009). Adoption of ICT in science education: A case study of communication channels in a teachers' professional development project. Eurasia Journal of Mathematics, Science \& Technology Education, 5(2), 103-118. 
Kansanen, P., Tirri, K., Meri, M., Krokfors, L., Husu, J., \& Jyrhämä, R. (2000). Teachers' pedagogical thinking: Theoretical landscapes, practical challenges. New York: Peter Lang Publishing Inc.

Katzenmeyer, M., \& Moller, G. (2001). Awakening the sleeping giant: Helping teachers develop as leaders. Thousand Oaks, CA: Corwin Press.

Korhonen, T., \& Lavonen, J. (2016). A new wave of learning in Finland - Get started with innovation! In educating for twenty-first century global capacities: International perspectives and practices. Springer. (THIS WILL BE PART OF THIS BOOK)

Korhonen, T., Lavonen, J., Kukkonen, M., Sormunen, K., \& Juuti, K. (2014). The innovative school as an environment for the design of educational innovations. In H. Niemi, J. Multisilta, L. Lipponen, \& M. Vivitsou, Finnish innovations and technologies in schools: Towards new ecosystems of learning (pp. 99-114). Rotterdam: Sense Publishers.

Krzywacki, H., Koistinen, L., \& Lavonen, J. (2012). Assessment in Finnish mathematics education: Various ways, various needs. 12th International Congress on Mathematical Education. Retrieved from http://www.icme12.org/upload/UpFile2/TSG/0732.pdf

Krzywacki, H., Lavonen, J., \& Juuti, K. (2015). There are no effective teachers in Finland - Only effective systems and professional teachers. In O.-S. Tan, \& W.-C. Liu (Eds.), Teacher effectiveness: Capacity building in a complex learning era. Singapore: Centage learning. Kupari, P., Välijärvi, J., Andersson, L., Arffman, I., Nissinen, K., Puhakka, E., \& Vettenranta, J. (2013). PISA12 ensituloksia. Opetus-ja kulttuuriministeriö. Retrieved from http://www. minedu. fi/export/sites/default/OPM/Julkaisut/2013/liitteet/okm20.pdf

Kärnä, P., \& Rautopuro, J. (2013). Mitä on oppimistulosten taustalla. In A. Räisänen (Ed.), Oppimisen arvioinnin kontekstit käytännöt. Raportit ja selvitykset 3/2013. (pp. 187-211). 
Helsinki: National Board of Education. Retrieved from http://www.oph.fi/download/149650_Oppimisen_arvioinnin_kontekstit_ja_kaytannot_2.p df

Laukkanen, R. (2008). Finnish strategy for high-level education for all. In N. C. Soguel, \& P. Jaccard (Eds.), Governance and performance of education systems (pp. 305-324). Netherlands: Springer.

Lavonen, J. (2007). National science education standards and assessment in Finland. In D. J. Waddington, P. Nentwig, \& S. Schaze (Eds.), Making it comparable (pp. 101-126). Berlin: Waxmann.

Lavonen, J., Juuti, K., Aksela, M., \& Meisalo, V. (2006). A professional development project for improving the use of information and communication technologies in science teaching. Technology, pedagogy and education, 15(2), 159-174.

Lavonen, J., Korhonen, T., Kukkonen, M. \& Sormunen, K. (2014) Rajaton luokkahuone. In Niemi, H. \& Multisilta, J. (Eds.). Innovatiivinen koulu (pp. 86-113 ) Jyväskylä: PSkustannus.

Lavonen, J., Krzywacki-Vainio, H., Aksela, M., Krokfors, L., Oikkonen, J., \& Saarikko, H. (2007). Pre-service teacher education in chemistry, mathematics and physics. In E. Pehkonen, M. Ahtee, \& J. Lavonen (Eds.), How Finns learn mathematics and science (pp. 49-67). Sense Publishers.

Lieberman, A. (1992). Teacher leadership: What are we learning? In C. Livingston (Ed.), Teachers as leaders: Evolving roles (pp. 159-166). Washington, D.C., United States: National Education Association. 
Maier, U. (2009). Towards state-mandated testing in Germany: How do teachers assess the pedagogical relevance of performance feedback information? Assessment in Education: Principles, Policy \& Practice, 16(2), 205-226.

Niemi, H., \& Lavonen, J. (2012). Evaluation for improvements in Finnish teacher education. In J. Harford, B. Hudson, \& H. Niemi (Eds.), Quality assurance and teacher education: International challenges and expectations. Oxford, United Kingdom: Peter Lang.

Niemi, H., Toom, A., \& Kallioniemi, A. (2012). Miracle of education: The principles and practices of teaching and learning in Finnish schools. Sense Publishers.

OECD. (2005). Definition and selection of competencies (DeSeCo): Executive summary. Paris: OECD Publishing. Retrieved 10 11, 2015, from http://www.oecd.org/pisa/35070367.pdf OECD. (2006). Are students ready for a technology-rich world? What PISA studies tell us [No. 54931]. Paris: OECD Publishing. Retrieved 10 11, 2015, from http://www.oecd.org/edu/school/programmeforinternationalstudentassessmentpisa/35995 145.pdf

OECD. (2007). PISA 2006: Science competencies for tomorrow's world, volume 1: Analysis. Paris: OECD Publishing. Retrieved from http://www.oecd.org/pisa/pisaproducts/39703267.pdf

OECD. (2010). PISA 2009: Volume 2: Data. . Paris: OECD Publishing. Retrieved from http://www.oecd.org/pisa/pisaproducts/48852584.pdf

OECD. (2012). OECD program for international student assessment 2012: School questionnaire for PISA 2012. Paris: OECD Publishing. Retrieved from http://pisa2012.acer.edu.au/downloads/MS12_ScQ_ENG.pdf 
OECD. (2013). PISA 2012. Results in focus. What 15-year-olds know and what they can do with what they know. Paris: OECD. Retrieved from http://www.oecd.org/pisa/keyfindings/pisa-2012-results-overview.pdf

OECD. (2014). Talis 2013 Results: An international perspective on teaching and learning. OECD Publishing. Retrieved from http://www.oecd-ilibrary.org/education/talis-2013results 9789264196261-en

Ouakrim-Soivio, N., Rinkinen, A. \& Karjalainen, T. (toim.) (2015). Tulevaisuuden peruskoulu. Opetus- ja kulttuuriministeriön julkaisuja 8:2015. http://www.minedu.fi/export/sites/default/OPM/Julkaisut/2015/liitteet/okm8.pdf?lang=fi

Piirto, J. (2011). Creativity for 21 st century skills: How to embed creativity into the curriculum. Sense Publishers.

Rogers, E. (2003). Diffusion of innovations, 5th edition. New York: Free Press.

Rotherham, A. J., \& Willingham, D. (2009). 21st century. Educational Leadership, 67(1), 16-21.

Sahlberg, P. (2011). Finnish lessons: What can the world learn from educational change in Finland? New York: Teachers College Press.

Simola, H. (1998). Decontextualizing teachers' knowledge: Finnish didactics and teacher education curricula during the 1980s and 1990s. Scandinavian Journal of Educational Research, 42(4), 325-338.

Simola, H. (2005). The Finnish miracle of PISA; historical and sociological remarks on teaching and teacher education. Comparative Education, 41(4), 455-470.

Simola, H., Rinne, R., Varjo, J., Pitkänen, H., \& Kauko, J. (2009). Quality assurance and evaluation (QAE) in Finnish compulsory schooling: A national model or just unintended effects of radical decentralisation? Journal of Education Policy, 24(2), 163-178. 
Simola, H., Rinne, R., Varjo, J., Pitkänen, H., \& Kauko, J. (2009). Quality assurance and evaluation (QAE) in Finnish compulsory schooling: a national model or just unintended effects of radical decentralisation? Journal of Education Policy, 24(2), 163-178.

Spady, W. G. (2003). Outcome-based education. In J. W. Guthrie (Ed.), Encyclopedia of education 2nd edition (pp. 1827-1831). New York: Macmillan Reference.

Taajamo, M., Puhakka, E., \& Välijärvi, J. (2014). Opetuksen ja oppimisen kansainvälinen tutkimus TALIS 2013; Yläkoulun ensituloksia. Opetus- ja kulttuuriministeriö. Retrieved from http://www.minedu.fi/export/sites/default/OPM/Julkaisut/2014/liitteet/okm15.pdf?lang=fi

Trilling, B., \& Fadel, C. (2009). 21st century skills: Learning for life in our times. San Francisco: John Wiley \& Sons.

Vahtivuori-Hänninen, S., Irmeli, H., Niemi, H., Lavonen, J., Lipponen, L., \& Multisilta, J. (2014). A new Finnish national core curriculum for basic education (2014) and technology as an integrated tool for learning. In Niemi, H., Multisilta, J., Lipponen, L. \& M. Vivitsou (Eds.), Finnish innovations and technologies in schools (pp. 21-32). Sense Publishers.

Vitikka, E., Krokfors, L., \& Hurmerinta, E. (2012). The Finnish national core curriculum. In Niemi, H., Toom, A. \& Kallioniemi, A. (Eds.) Miracle of education (pp. 83-96). Sense Publishers. 